\title{
PENGARUH PEMBERIAN ASI EKSKLUSIF DENGAN KEJADIAN ISPA PADA ANAK BATITA DI PUSKESMAS SINGOSARI KOTA PEMATANGSIANTAR
}

\author{
Sri Hernawati Sirait \\ (Prodi Kebidanan Pematangsiantar Poltekkes Kemenkes Medan)
}

\begin{abstract}
ABSTRAK
Pendahuluan: Infeksi Saluran Pernafasan Akut (ISPA) merupakan penyebab terpenting morbiditas dan mortalitas pada anak. Kelompok usia 6 - 23 bulan adalah kelompok umur yang paling rentan untuk mengalami ISPA. Berdasarkan World Health Organization (WHO) dan Departemen Kesehatan Indonesia tahun 2008, pneumonia yang merupakan salah satu jenis ISPA adalah penyebab paling banyak kematian balita di dunia dan juga di Indonesia. Penyakit ISPA menduduki peringkat pertama dari 10 penyakit terbesar rawat jalan di Puskesmas Singosari Pematangsiantar. Terdapat 1.569 kasus ISPA untuk semua golongan umur. ISPA di Puskesmas Singosari pada bayi usia 6 - 23 bulan dari bulan Januari 2013 hingga Februari 2014 terdapat 296 kasus. Tujuan penelitian untuk mengetahui pengaruh pemberian ASI eksklusif dengan kejadian ISPA pada anak batita di Wilayah Kerja Puskesmas Singosari Kota Pematangsiantar. Tujuan penelitian untuk mengetahui pengaruh pemberian ASI eksklusif dengan kejadian ISPA pada anak batita. Metode: Jenis penelitian analitik observasional dengan rancangan penelitian kohort retrosfektif. Populasi adalah seluruh anak batita yang berkunjung ke Puskesmas Singosari dari bulan Januari 2013 - Februari 2014 sebanyak 382 kasus di Wilayah Kerja Puskesmas Singosari Pematangsiantar dengan kriteria inklusi dalam penelitian ini yaitu : Anak batita yang datang berobat ke Puskesmas, Responden bertempat tinggal di Wilayah Kerja Puskesmas Singosari dan Kriteria eksklusi dalam penapisan ini, yaitu : Anak yang menderita penyakit kronis dan Anak yang menderita gizi buruk. Metode pengambilan sampel dengan Simple Random Sampling didapat sampel sebanyak 79 orang anak batita penderita ISPA. Analisis bivariat dilakukan dengan uji chi square dengan tingkat kemaknaan $p<0,05$. Hasil: Ada pengaruh pemberian ASI eksklusif dengan kejadian ISPA, hasil uji statistik chi-square didapat nilai $p=0,002$. Karakteristik anak dengan kejadian ISPA yang berhubungan yaitu anggota keluarga yang merokok, dengan nilai $p=0.005$. Saran: Diharapkan ibu-ibu yang memiliki batita untuk dapat memperhatikan atau menambah gizi pada anaknya dan memperhatikan kelengkapan imunisasinya dan kepada petugas kesehatan diharapkan dapat meningkatkan cakupan ASI eksklusif diperlukan monitoring langsung dari bidan terhadap ibu nifas untuk memberikan ASI eksklusif.
\end{abstract}

Kata Kunci : ASI ekslusif, kejadian ISPA.

\section{PENDAHULUAN}

\section{Latar Belakang}

Penurunan kasus kematian pada anak merupakan salah satu hal yang dianggap penting dalam tujuan pembangunan Millenium Development Goals (MDG's) yang diadopsi dari Konferensi Tingkat Tinggi (KTT) Millenium 2000 yang terdapat pada target ke empat dari kedelapan tujuan tersebut. Pada kasus kematian yang tinggi biasanya jumlah kematian terbanyak terjadi pada usia balita saat mereka rentan terhadap penyakit. Statistik menunjukkan bahwa lebih dari $70 \%$ kematian balita disebabkan diare, pneumonia, campak, malaria, dan malnutrisi (Kementrian Kesehatan RI, 2012).

Infeksi Saluran Pernafasan Akut (ISPA) merupakan penyebab terpenting morbiditas dan mortalitas pada anak. Kelompok usia 6-23 bulan adalah kelompok umur yang paling rentan untuk mengalami ISPA. Berdasarkan World Health Organization (WHO) dan Departemen Kesehatan Indonesia tahun 2008,pneumonia yang merupakan salah satu jenis ISPA adalah penyebab paling banyak kematian balita di dunia dan juga di Indonesia (Pediatri, 2009).

Secara global tingkat kematian balita mengalami penurunan. Menurut World Health Statistik 2012 angka kematian balita (AKABA) terendah dicapai Singapura yaitu 3 kematian per 1000 kelahiran hidup, sedangkan yang tertinggi adalah Myanmar yaitu sebesar 66 kematian per 1000 kelahiran hidup. Dikawasan Association of South East Asia Nation (ASEAN) Indonesia menempati peringkat ke empat tertinggi kematian balitanya setelah Myanmar,Laos dan Kamboja (Kementrian Kesehatan RI, 2012).

Di Indonesia ada 6 provinsi yang masuk kategori AKABA tertinggi yaitu Sumatera Barat, Nusa Tenggara Timur, Nusa Tenggara Barat, Maluku, Kalimantan Selatan, Maluku Utara. Berdasarkan hasil survei Demografi dan Kesehatan Indonesia (SDKI) tahun 2012 diperoleh bahwa AKABA di Sumatera Utara sebesar 54 per 1.000 kelahiran hidup. Sedangkan angka rata-rata nasional pada tahun 
2012 sebesar 43 per 1.000 kelahiran hidup. Angka nasional ini mengalami sedikit penurunan dibandingkan AKABA pada tahun 2007 yaitu sebesar 44 per 1.000 kelahiran hidup (Profil Kesehatan Sumatera Utara, 2012).

Di negara berkembang, lebih dari 10 juta bayi meninggal dunia per tahun, 2/3 dari kematian tersebut terkait dengan masalah gizi yang sebenarnya dapat dihindarkan. Penelitian di 42 negara berkembang menunjukkan bahwa pemberian ASI eksklusif selama 6 bulan merupakan intervensi kesehatan masyarakat yang mempunyai dampak positif terbesar untuk menurunkan angka kematian balita, yaitu sekitar 13\% (Sentra Laktasi Indonesia, 2007).

Hasil penelitian Lopez-Alarcon di negara maju, ASI dapat menurunkan angka infeksi saluran pernafasan bawah, otitis media (infeksi pada telinga tengah), meningitis bakteri (radang selaput otak), infeksi saluran kemih, dan diare. Protein yang terdapat pada ASI adalah protein yang spesifik untuk manusia, maka pengenalan lebih lama terhadap protein asing atau protein lain yang terdapat di dalam susu formula, dapat mengurangi dan memperlambat terjadinya alergi ( Proverawati,dkk, 2010).

Cakupan persentase bayi yang diberi ASI Eksklusif di Sumatera Utara dari tahun 2004-2012 cenderung menurun secara signifikan, hanya pada tahun 2008 mengalami peningkatan sebesar 10,33\% dibanding tahun 2007. Dan pencapaian pada tahun 2012 sebesar 20,33\% merupakan pencapaian terendah selama kurun waktu 2004-2012. Terdapat 8 kabupaten/kota yang pencapaian ASI Eksklusif 0\% yaitu Kabupaten Tapanuli Tengah, Dairi, Karo, Langkat, Pakpak Barat, Padang Lawas, Kota Medan dan Gunung Sitoli. Pencapaian tertinggi ada di Kabupaten Labuhan Batu Utara yaitu 68,81\% (Profil Kesehatan Sumatera Utara, 2012).

Penyakit ISPA ternyata menduduki peringkat pertama dari 10 penyakit terbesar rawat jalan di Puskesmas Singosari Pematangsiantar. Terdapat 1.569 kasus ISPA untuk semua golongan umur. ISPA di Puskesmas Singosari pada bayi usia $6-23$ bulan dari bulan Januari 2013 hingga Februari 2014 terdapat 296 kasus (Puskesmas Singosari, 2014).

Survey awal yang dilakukan peneliti di Puskesmas Singosari Pematangsiantar pada bulan HASIL PENELITIAN Analisis Univariat
Maret 2014, diperoleh data dari tenaga kesehatan terdapat 296 kasus penderita ISPA yang terjadi pada anak batita yang disebabkan oleh beberapa faktor yaitu rendahnya pemberian ASI eksklusif, status gizi kurang, imunisasi tidak lengkap, lingkungan, pengaruh musim dan masalah kesehatan anak lainnya. Setelah dilakukan wawancara pada 8 orang ibu yang memiliki anak batita yang menderita ISPA, ada 6 orang ibu mengatakan tidak menyusui bayi nya dengan ASI ekslusif. Berdasarkan wawancara tersebut, penulis tertarik untuk melakukan penelitian mengenai pengaruh pemberian ASI eksklusif dengan kejadian ISPA pada anak batita di Puskesmas Singosari Kota Pematangsiantar.

\section{Perumusan Masalah}

Berdasarkan latar belakang diatas yang menjadi permasalahan pada penelitian ini adalah "Adakah pengaruh pemberian ASI eksklusif dengan kejadian ISPA pada anak batita di Puskesmas Singosari Kota Pematangsiantar?”.

\section{Tujuan Penelitian}

Untuk mengetahui pengaruh pemberian ASI eksklusif dengan kejadian ISPA pada anak batita di Puskesmas Singosari Kota Pematangsiantar.

\section{Metode Penelitian}

Jenis penelitian analitik observasional dengan rancangan penelitian kohort retrosfektif. Populasi adalah seluruh anak batita yang berkunjung ke Puskesmas Singosari dari bulan Januari 2013 - Februari 2014 sebanyak 382 kasus di Puskesmas Singosari Pematangsiantar dengan kriteria inklusi dalam penelitian ini yaitu : Anak batita yang datang berobat ke Puskesmas, Responden bertempat tinggal di Puskesmas Singosari dan Kriteria eksklusi dalam penapisan ini, yaitu : Anak yang sedang menderita penyakit kronis dan Anak yang sedang menderita gizi buruk. Metode pengambilan sampel dengan Simple Random Sampling didapat sampel sebanyak 79 orang anak batita penderita ISPA. Analisis bivariat dilakukan dengan uji chi square dengan tingkat kemaknaan $p<$ 0,05 .

Tabel 1. Distribusi Frekuensi Pemberian ASI Eksklusif dan Kejadian ISPA Pada Anak Batita di Puskesmas Singosari Kota Pematangsiantar

\begin{tabular}{llccc}
\hline No & Variabel & Kategori & f & \% \\
\hline 1. & Pemberian ASI & Eksklusif & 19 & 24,1 \\
& & Tidak Eksklusif & 60 & 75,9 \\
2. & Kejadian ISPA & ISPA & 57 & 72,2 \\
& & Tidak ISPA & 22 & 27,8 \\
\hline
\end{tabular}

Dari tabel 1 dapat dilihat bahwa berdasarkan pemberian ASI eksklusif pada anak batita mayoritas responden tidak mendapatkan ASI eksklusif yaitu sebanyak 60 orang $(75.9 \%)$ dan berdasarkan kejadian ISPA pada anak batita mayoritas responden mengalami ISPA yaitu sebanyak 57 orang (72.2\%). 
Tabel 2. Distribusi Frekuensi Karakteristik Ibu Berdasarkan Umur, Pendidikan, Pekerjaan, dan Paritas di Puskesmas Singosari Kota Pematangsiantar

\begin{tabular}{|c|c|c|c|c|}
\hline No & $\begin{array}{c}\text { Karakteristik } \\
\text { Ibu }\end{array}$ & Kategori & $\mathrm{f}$ & $\%$ \\
\hline \multirow[t]{3}{*}{1} & Umur & $<20$ Tahun & 20 & $25.3 \%$ \\
\hline & & 20 - 35 Tahun & 38 & $48.1 \%$ \\
\hline & & $>35$ Tahun & 21 & $26.6 \%$ \\
\hline \multirow[t]{2}{*}{2.} & Pendidikan & Pendidikan Tinggi (SMA,PT) & 32 & $40.5 \%$ \\
\hline & & Pendidikan Rendah (SD,SMP) & 47 & $59.5 \%$ \\
\hline \multirow[t]{3}{*}{3.} & Pekerjaan & Bekerja & & $36.7 \%$ \\
\hline & & Tidak bekerja & 29 & $63.3 \%$ \\
\hline & & & 50 & \\
\hline \multirow[t]{2}{*}{4.} & Paritas & $<2$ & & $40.5 \%$ \\
\hline & & $>2$ & 32 & $59.5 \%$ \\
\hline
\end{tabular}

Dari tabel 2 dapat dilihat bahwa berdasarkan umur mayoritas responden berusia 20 - 35 tahun sebanyak 38 orang $(48.1 \%)$, berdasarkan pendidikan mayoritas responden memiliki pendidikan rendah yaitu sebanyak 47 orang (59.5\%), berdasarkan pekerjaan mayoritas responden tidak bekerja yaitu sebanyak 50 orang $(63.3 \%)$ dan berdasarkan paritas mayoritas responden memiliki paritas $>2$ anak yaitu sebanyak 47 orang $(59.5 \%)$.

Tabel 3. Distribusi Frekuensi Karakteristik Anak

Berdasarkan Status Gizi, Status Imunisasi dan Anggota Keluarga Yang Merokok di Puskesmas Singosari Kota Pematangsiantar

\begin{tabular}{cllcc}
\hline No & \multicolumn{1}{c}{ Karakteristik Anak } & Kategori & $\mathrm{f}$ & $\%$ \\
\hline 1. & Status Gizi & Gizi Baik & 77 & $97.5 \%$ \\
& & Gizi Kurang & 2 & $2.5 \%$ \\
& & & \\
\hline 2. & Status Imunisasi & Lengkap & 79 & $100 \%$ \\
& & Tidak Lengkap & 0 & 0 \\
\hline & & & 79 & $100 \%$ \\
\hline 3. & Jumlah & Ya & 53 & $67.1 \%$ \\
& & Tidak & 26 & $32.9 \%$ \\
\hline
\end{tabular}

Dari tabel 3 dapat dilihat berdasarkan status gizi 79 orang (100\%) dan berdasarkan anggota keluarga yang mayoritas responden memiliki status gizi baik yaitu sebanyak 77 orang $(97.5 \%)$, berdasarkan status imunisasi seluruh responden memiliki status imunisasi lengkap yaitu merokok mayoritas respoden memiliki anggota keluarga yang perokok yaitu sebanyak 53 orang (67.1\%).

Analisis Bivariat

Tabel 4. Tabulasi Silang Pengaruh Pemberian ASI Eksklusif Dengan Kejadian ISPA Pada Anak Batita Di Puskesmas Singosari Kota Pematangsiantar

\begin{tabular}{|c|c|c|c|c|c|c|c|c|}
\hline \multirow{2}{*}{$\begin{array}{l}N \\
0\end{array}$} & \multirow{2}{*}{$\begin{array}{c}\text { Pemberian ASI eksklusif } \\
\text { dengan kejadian ISPA }\end{array}$} & \multicolumn{2}{|c|}{ ISPA } & \multicolumn{2}{|c|}{ Tidak ISPA } & \multicolumn{2}{|c|}{ Jumlah } & \multirow{2}{*}{$\begin{array}{l}\text { Nilai } \\
p\end{array}$} \\
\hline & & $\mathrm{n}$ & $\%$ & $\mathrm{n}$ & $\%$ & $\mathrm{n}$ & $\%$ & \\
\hline \multirow[t]{4}{*}{1} & Pemberian ASI Eksklusif & & & & & & & \\
\hline & 1. ASI Eksklusif & 8 & $10.1 \%$ & 11 & $13.9 \%$ & 19 & $24.1 \%$ & 0.002 \\
\hline & 2. Tidak ASI Eksklusif & 49 & $62.0 \%$ & 11 & $13.9 \%$ & 60 & $75.9 \%$ & \\
\hline & Jumlah & 57 & $77.2 \%$ & 22 & $27.8 \%$ & 79 & $100 \%$ & \\
\hline
\end{tabular}

Pengaruh pemberian ASI eksklusif dengan kejadian ISPA pada anak batita diperoleh bahwa dari 19 anak $(24.1 \%)$ yang mendapat ASI eksklusif ada 8 anak (10.1\%) yang terkena ISPA. Dan dari 60 orang (75.9\%) anak yang tidak mendapat ASI eksklusif ada 49 orang (62.0\%) anak yang terkena ISPA. Hasil uji statistik chisquare didapat nilai $\mathrm{p}=0,002$ artinya ada hubungan pemberian ASI eksklusif dengan kejadian ISPA. 
Tabel 5. Tabulasi Silang Karakteristik Ibu Meliputi Umur, Pendidikan, Pekerjaan dan Paritas Dengan Kejadian ISPA Pada Anak Batita Di Puskesmas Singosari Kota Pematangsiantar

\begin{tabular}{|c|c|c|c|c|c|c|c|c|c|}
\hline \multirow{2}{*}{$\begin{array}{l}\mathrm{N} \\
\mathrm{O}\end{array}$} & \multirow{2}{*}{\multicolumn{2}{|c|}{ Karakteristik Ibu }} & \multicolumn{2}{|c|}{ ISPA } & \multicolumn{2}{|c|}{ Tidak ISPA } & \multicolumn{2}{|c|}{ Jumlah } & \multirow{2}{*}{$\begin{array}{l}\text { Nilai } \\
\quad P\end{array}$} \\
\hline & & & $\mathrm{n}$ & $\%$ & $\mathrm{n}$ & $\%$ & $\mathrm{n}$ & $\%$ & \\
\hline \multirow[t]{5}{*}{1} & Umur & & & & & & & & \multirow{4}{*}{0.309} \\
\hline & 1. $<20$ Tahun & & 12 & $15.2 \%$ & 8 & $10.1 \%$ & 20 & $25.3 \%$ & \\
\hline & 2. 20-35 Tahun & & 30 & $38.0 \%$ & 8 & $10.1 \%$ & 38 & $48.1 \%$ & \\
\hline & 3. $>35$ Tahun & & 15 & $19.0 \%$ & 6 & $7.6 \%$ & 21 & $26.6 \%$ & \\
\hline & Jumlah & & 57 & $72.2 \%$ & 22 & $27.8 \%$ & 79 & $100 \%$ & \\
\hline \multirow[t]{4}{*}{2} & Pendidikan Ibu & & & & & & & & \multirow{3}{*}{0.417} \\
\hline & $\begin{array}{l}\text { 1.Pendidikan } \\
\text { (SMA, PT) }\end{array}$ & Tinggi & 21 & $45.6 \%$ & 11 & $13.9 \%$ & 32 & $40.5 \%$ & \\
\hline & $\begin{array}{r}\text { 2.Pendidikan } \\
(\mathrm{SD}, \mathrm{SMP})\end{array}$ & Rendah & 36 & $45.6 \%$ & 11 & $13.9 \%$ & 47 & $59.5 \%$ & \\
\hline & Jumlah & & 57 & $72.2 \%$ & 22 & $27.8 \%$ & 79 & $100 \%$ & \\
\hline \multirow[t]{4}{*}{3} & Pekerjaan Ibu & & & & & & & & \multirow{3}{*}{0.458} \\
\hline & 1.Bekerja & & 19 & $24.1 \%$ & 10 & $12.7 \%$ & 29 & $36.7 \%$ & \\
\hline & 2.Tidak Bekerja & & 38 & $48.1 \%$ & 12 & $15.2 \%$ & 50 & $63.3 \%$ & \\
\hline & Jumlah & & 57 & $72.2 \%$ & 22 & $27.8 \%$ & 79 & $100 \%$ & \\
\hline \multirow[t]{4}{*}{4} & Paritas & & & & & & & & \multirow{3}{*}{0.067} \\
\hline & $1 .<2$ & & 19 & $24.1 \%$ & 13 & $16.5 \%$ & 32 & $40.5 \%$ & \\
\hline & 2.> 2 & & 38 & $48.1 \%$ & 9 & $11.4 \%$ & 47 & $59.5 \%$ & \\
\hline & Jumlah & & 57 & $72.2 \%$ & 22 & $27.8 \%$ & 79 & $100 \%$ & \\
\hline
\end{tabular}

Dari tabel 5 dapat dilihat bahwa hasil uji statistik chi-square karakteristik ibu : umur, pendidikan, pekerjaan dan paritas tidak berhubungan dengan kejadian ISPA pada anak batita

Tabel 6. Karakteristik Anak ( Status Gizi, Status Imunisasi, dan Anggota Keluarga Yang Merokok) Dengan Kejadian ISPA Pada Anak Batita

Di Puskesmas Singosari Kota Pematangsiantar

\begin{tabular}{|c|c|c|c|c|c|c|c|c|}
\hline \multirow{2}{*}{$\begin{array}{c}\mathrm{N} \\
\mathrm{O}\end{array}$} & \multirow{2}{*}{ Karakteristik Anak } & \multicolumn{2}{|c|}{ ISPA } & \multicolumn{2}{|c|}{ Tidak ISPA } & \multicolumn{2}{|c|}{ Jumlah } & \multirow{2}{*}{$\begin{array}{c}\text { Nilai } \\
P\end{array}$} \\
\hline & & $\mathrm{n}$ & $\%$ & $\mathrm{n}$ & $\%$ & $\mathrm{n}$ & $\%$ & \\
\hline \multirow[t]{4}{*}{1} & Status Gizi & & & & & & & \\
\hline & 1.Gizi Baik & 55 & $69.6 \%$ & 22 & $27.8 \%$ & 77 & $97.5 \%$ & 1.000 \\
\hline & 2.Gizi Kurang & 2 & $2.5 \%$ & 0 & $0 \%$ & 2 & $2.5 \%$ & \\
\hline & Jumlah & 57 & $72.2 \%$ & 22 & $27.8 \%$ & 79 & $100 \%$ & \\
\hline \multirow[t]{4}{*}{2} & Status Imunisasi & & & & & & & \\
\hline & 1.Lengkap & 57 & $72.2 \%$ & 22 & $27.8 \%$ & 79 & $100 \%$ & - \\
\hline & 2.Tidak Lengkap & 0 & 0 & 0 & 0 & 0 & 0 & \\
\hline & Jumlah & 57 & $72.2 \%$ & 22 & $27.8 \%$ & 79 & $100 \%$ & \\
\hline \multirow[t]{4}{*}{3} & $\begin{array}{l}\text { Anggota Keluarga } \\
\text { yang Merokok }\end{array}$ & & & & & & & \\
\hline & 1. Ya & 44 & $55.7 \%$ & 9 & $11.4 \%$ & 53 & $67.1 \%$ & 0.005 \\
\hline & 2. Tidak & 13 & $16.5 \%$ & 13 & $16.5 \%$ & 26 & $32.9 \%$ & \\
\hline & Jumlah & 57 & $72.2 \%$ & 22 & $27.8 \%$ & 79 & $100 \%$ & \\
\hline
\end{tabular}

Dari tabel 6 diatas dapat diketahui bahwa hasil uji statistik chi-square pengaruh anggota yang merokok dengan kejadian ISPA pada anak batita diperoleh nilai $p=$ 0,005 artinya ada hubungan anggota yang merokok terhadap pengaruh pemberian ASI eksklusif dengan kejadian ISPA.
Pada semua variabel counfounding (umur, pendidikan, pekerjaan, paritas, status imunisasi, dan status gizi) tidak menunjukkan hubungan yang bermakna karena nilai $p>0,05$. Dari tabel diatas variabel counfounding berpotensial menjadi variabel pengganggu tidak memenuhi syarat karena tidak ada berhubungan dengan variabel 
dependen. Tetapi untuk membuktikan bahwa variabel variabel independen dapat dilihat dari tabel 7 . counfounding mempunyai hubungan interaksi terhadap

Tabel 7. Tabulasi Silang Sosiodemografi Karakteristik Ibu dan Anak Terhadap Pemberian ASI Eksklusif di Puskesmas Singosari Kota Pematangsiantar

\begin{tabular}{|c|c|c|c|c|c|c|c|c|c|}
\hline \multirow{3}{*}{$\begin{array}{c}\mathrm{N} \\
\mathrm{O}\end{array}$} & \multirow{3}{*}{\multicolumn{2}{|c|}{ Variabel Counfonding }} & \multicolumn{4}{|c|}{ Pemberian ASI Eksklusif } & \multirow{2}{*}{\multicolumn{2}{|c|}{ Jumlah }} & \multirow{3}{*}{$\begin{array}{c}\text { Nilai } \\
p\end{array}$} \\
\hline & & & \multicolumn{2}{|c|}{$\mathrm{Ya}$} & \multicolumn{2}{|c|}{ Tidak } & & & \\
\hline & & & $\mathrm{n}$ & $\%$ & $\mathrm{n}$ & $\%$ & $\mathrm{n}$ & $\%$ & \\
\hline \multirow[t]{5}{*}{1} & Umur & & & & & & & & \multirow{4}{*}{0.131} \\
\hline & 1. $<20$ Tahun & & 8 & $10.1 \%$ & 12 & $15.2 \%$ & 20 & $25.3 \%$ & \\
\hline & 2. 20-35 Tahun & & 8 & $10.1 \%$ & 30 & $38.0 \%$ & 38 & $48.1 \%$ & \\
\hline & 3. > 35 Tahun & & 3 & $3.8 \%$ & 18 & $22.8 \%$ & 21 & $26.6 \%$ & \\
\hline & Jumlah & & 19 & $24.1 \%$ & 60 & $75.9 \%$ & 79 & $100 \%$ & \\
\hline \multirow[t]{4}{*}{2} & Pendidikan Ibu & & & & & & & & \multirow{3}{*}{0.133} \\
\hline & $\begin{array}{r}\text { 1.Pendidikan } \\
\text { (SMA, PT) }\end{array}$ & Tinggi & 11 & $13.9 \%$ & 21 & $26.6 \%$ & 32 & $40.5 \%$ & \\
\hline & $\begin{array}{r}\text { 2.Pendidikan } \\
\text { (SD, SMP) }\end{array}$ & Rendah & 8 & $10.1 \%$ & 39 & $49.4 \%$ & 47 & $59.5 \%$ & \\
\hline & Jumlah & & 19 & $24.1 \%$ & 60 & $75.9 \%$ & 79 & $100 \%$ & \\
\hline \multirow[t]{4}{*}{3} & Pekerjaan Ibu & & & & & & & & \multirow{3}{*}{0.774} \\
\hline & 1.Bekerja & & 8 & $10.1 \%$ & 21 & $26.6 \%$ & 29 & $36.7 \%$ & \\
\hline & 2.Tidak Bekerja & & 11 & $13.9 \%$ & 39 & $49.4 \%$ & 50 & $63.3 \%$ & \\
\hline & Jumlah & & 19 & $24.1 \%$ & 60 & $75.9 \%$ & 79 & $100 \%$ & \\
\hline \multirow[t]{4}{*}{4} & Paritas & & & & & & & & \multirow{3}{*}{0.333} \\
\hline & $1 .<2$ & & 10 & $12.7 \%$ & 22 & $27.8 \%$ & 32 & $40.5 \%$ & \\
\hline & $2 .>2$ & & 9 & $11.4 \%$ & 38 & $48.1 \%$ & 47 & $59.5 \%$ & \\
\hline & Jumlah & & 19 & $24.1 \%$ & 60 & $75.9 \%$ & 79 & $100 \%$ & \\
\hline \multirow[t]{4}{*}{5} & Status Gizi & & & & & & & & \multirow{3}{*}{1.000} \\
\hline & 1.Gizi Baik & & 19 & $24.1 \%$ & 58 & $73.4 \%$ & 77 & $97.5 \%$ & \\
\hline & 2.Gizi Kurang & & 0 & $0 \%$ & 2 & $2.5 \%$ & 2 & $2.5 \%$ & \\
\hline & Jumlah & & 19 & $24.1 \%$ & 60 & $75.9 \%$ & 79 & $100 \%$ & \\
\hline \multirow[t]{4}{*}{6} & Status Imunisasi & & & & & & & & \multirow{3}{*}{-} \\
\hline & 1.Lengkap & & 19 & $24.1 \%$ & 60 & $75.9 \%$ & 79 & $100 \%$ & \\
\hline & 2.Tidak Lengkap & & 0 & $0 \%$ & 0 & $0 \%$ & 0 & 0 & \\
\hline & Jumlah & & 19 & $24.1 \%$ & 60 & $75.9 \%$ & 79 & $100 \%$ & \\
\hline \multirow[t]{4}{*}{7} & $\begin{array}{l}\text { Anggota Keluarga } \\
\text { yang Merokok }\end{array}$ & & & & & & & & \multirow{3}{*}{0.890} \\
\hline & 1. $\mathrm{Ya}$ & & 12 & $15.2 \%$ & 41 & $51.9 \%$ & 53 & $67.1 \%$ & \\
\hline & 2. Tidak & & 7 & $8.9 \%$ & 19 & $24.1 \%$ & 26 & $32.9 \%$ & \\
\hline & Jumlah & & 19 & $24.1 \%$ & 60 & $75.9 \%$ & 79 & $100 \%$ & \\
\hline
\end{tabular}

Dari tabel 7 diatas dapat diketahui bahwa hasil uji statistik chi-square sosiodemografi karakteristik ibu dan anak terhadap pemberian ASI eksklusif tidak ada yang berhubungan.

\section{PEMBAHASAN}

1. Faktor Pengaruh Pemberian ASI Eksklusif Dengan Kejadian ISPA

Pengaruh pemberian ASI eksklusif dengan kejadian ISPA pada anak batita diperoleh data bahwa dari 19 anak (24.1\%) yang mendapat ASI eksklusif ada 8 anak (10.1\%) yang terkena ISPA. Dan dari 60 orang (75.9\%) anak yang tidak mendapat ASI eksklusif ada 49 orang (62.0\%) anak yang terkena ISPA. Hasil uji statistik chi-square didapat nilai $p=0,002$ artinya ada hubungan anggota yang merokok terhadap pengaruh pemberian ASI eksklusif dengan kejadian ISPA.

Penelitian ini sejalan dengan penelitian Widya (2013) yang mendapatkan bahwa pemberian ASI eksklusif memiliki hubungan dengan kejadian ISPA, hasil uji chisquare dengan tingkat kepercayaan 95\% $(\alpha=0,05)$ didapat hasi $p=0.002$. Hasil penelitian Sulistyoningsih, dkk bahwa balita yang mendapatkan ASI eksklusif memiliki resiko menderita ISPA sebesar 2 kali lipat dibandingkan balita yang mendapatkan ASI eksklusif.

Hasil penelitian di Amerika Serikat menunjukkan bahwa bayi yang mendapat ASI 4-6 bulan lebih besar risikonya menderita pneumonia dibandingkan bayi yang mendapat ASI lebih dari 6 bulan. Hasil penelitian LopezAlarcon et al (2007) menyimpulkan bahwa pemberian ASI 
penuh pada usia 4 bulan bermakna mengurangi kejadian ISPA dibandingkan dengan hanya diberi susu formula saja, dan pada usia 6 bulan tidak ada perbedaan yang bermakna antara pemberian ASI penuh dan susu formula. Hal ini menunjukkan bahwa manfaat anti infeksi ini akan bekerja maksimal untuk 3 bulan pertama usia bayi (Finberg \& Kleinman dalam Fauzi 2008).

Hasil tabulasi silang antara pemberian ASI eksklusif dengan pekerjaan didapat hasil bahwa dari 50 orang $(63.3 \%)$ ibu yang tidak bekerja terdapat 39 orang (49.4\%) ibu yang tidak memberikan ASI eksklusif. Sementara hasil tabulasi silang antara anggota yang merokok dengan dengan pemberian ASI eksklusif didapat dari 53 orang $(67.1 \%)$ ada anggota yang merokok yang tidak mendapatkan ASI eksklusif sebanyak 41 orang (51.9\%) anak. Hal ini dapat disimpulkan bahwa anak yang tidak diberikan ASI eksklusif dan terpaparnya anggota keluarga yang merokok dapat menyebabkan penyakit ISPA pada anak.

Pemberian ASI eksklusif selama 6 bulan atau lebih memberikan efek protektif yang lebih besar berkaitan dengan respon dosis efek protektif yang dihasilkan. Semakin besar dosis ASI yang diberikan semakin besar pula efek protektif yang dihasilkan. Hal ini dapat dijelaskan bahwa ASI sebagai proteksi pasif berpengaruh terhadap respon imun sistem anak dengan maturasional, anti inflamasi, imunomodulator, dan antimikrobial. Beberapa efek imun yang bisa ditimbulkan dalam bentuk perpanjangan proteksi terhadap ISPA. Respon imun berkaitan dengan dosis ASI bekerja secara biologikal selama 4 bulan atau 6 bulan atau bahkan beberapa tahun. ASI dapat juga memberikan perlindungan jangka panjang melalui stimulasi respon imun aktif. Imunitasi aktif merupakan imunitas spesifik dimana sistem imun membentuk memori jangka panjang terhadap paparan antigen tertentu (USAID, 2010).

Menurut Abdullah (2003) pemberian ASI terbukti efektif bagi perkembangan dan imunitas anak. Pemberian ASI cukup memberikan efek protektif terhadap ISPA pada batita, sedangkan batita masih rentan terhadap penyakit ISPA karena ASI yang tidak diberikan sesuai kebutuhan 06 bulan, makanan pendamping yang diberikan belum memenuhi gizi yang baik serta kurangnya menjaga kebersihan individu dan lingkungan. Hal ini membuktikan keadaan di lapangan masih kurang baik dalam pemenuhan gizi yang sesuai kebutuhan dalam pencegahan ISPA.

\section{Faktor Umur Ibu Yang Mempengaruhi Pemberian ASI Eksklusif Dengan Kejadian ISPA}

Pengaruh umur dengan kejadian ISPA pada anak batita diperoleh data bahwa dari 20 orang $(25.3 \%)$ ibu kelompok umur < 20 tahun ada 12 orang (15.2\%) ibu memiliki anak yang terkena ISPA. Dari 38 orang $(48.1 \%)$ kelompok umur 20 - 35 tahun ada 30 orang $(38.0 \%)$ ibu yang memiliki anak terkena ISPA. Dari 21 orang (26.6) kelompok umur > 35 tahun ada 15 orang (19.0) yang memiliki anak terkena ISPA. Hasil uji statistik chi-square didapat nilai $\mathrm{p}=0,309$ artinya tidak ada hubungan umur terhadap pengaruh pemberian ASI eksklusif dengan kejadian ISPA.

Hasil tabulasi silang antara umur ibu dan anggota yang merokok didapatkan bahwa dari 38 orang (48.1\%) ibu responden yang berumur $20-35$ tahun ada 28 orang (35.4\%) ibu yang anggota keluarga dirumah yang merokok. Adanya anggota keluarga yang merokok merupakan salah satu faktor resiko bagi keluarga dapat terkena ISPA.

Hasil tabulasi silang antara umur dengan pemberian ASI eksklusif didapat bahwa dari $38(48.1 \%)$ orang ibu yang memiliki anak terkena ISPA responden yang berumur 20 - 35 tahun ada 30 orang (38\%) ibu yang tidak memberikan ASI eksklusif kepada anaknya.

Umur tidak berhubungan dengan kejadian ISPA namun pada hasil tabulasi silang penelitian ini usia ibu dari umur 20-35 tahun banyak yang tidak memberikan ASI eksklusif disamping itu ibu yang berumur 20 - 35 tahun yang memiliki anak terkena ISPA banyak terpapar anggota keluarga merokok dirumah dan ibu yang berumur 20 - 35 tahun mayoritas memiliki pendidikan rendah. Kurangnya pemberian ASI eksklusif dan terpaparnya asap rokok pada anak merupakan faktor resiko terjadinya ISPA.

\section{Faktor Pendidikan Ibu Yang Mempengaruhi Pemberian ASI Eksklusif Dengan Kejadian ISPA}

Pada penelitian ini di temukan responden berdasarkan pendidikan adalah SMA dan Perguruan Tinggi. Pengaruh pendidikan dengan kejadian ISPA pada anak batita diperoleh data bahwa dari 32 ibu (40.5\%) dengan pendidikan tinggi ada $21(26.6 \%)$ ibu yang memiliki anak terkena ISPA. Dan dari 47 orang (59.5\%) ibu dengan pendidikan rendah ada 36 orang $(45.6 \%) \mathrm{ibu}$ memiliki anak yang terkena ISPA. Hasil uji statistik chisquare nilai $\mathrm{p}=0,417>\alpha=0,05$ artinya tidak ada hubungan pendidikan terhadap pengaruh pemberian ASI eksklusif dengan kejadian ISPA.

Hasil penelitian ini sejalan didukung oleh Bachrach et al (2003) yang mendapatkan bahwa pendidikan ibu tidak memiliki hubungan bermakna dengan kejadian ISPA $(\mathrm{RR}=0.62 \% ; \mathrm{CI}=95 \%=0.14 \%-2.93 \%)$, hasil penelitian Koch et al (2003) menunjukkan tidak ada hubungan yang bermakna antara pendidikan ibu yang tidak sekolah dengan kejadian ISPA (RR $=1.30 \% ; \mathrm{CI}=95 \%=0.81 \%-2,07 \%)$ dan hasil penelitian ini sejalan dengan Fauzi (2008) yang menyatakan bahwa tidak ada hubungan antara pendidikan ibu dengan kejadian ISPA ( $R R=0.9 \% ; \mathrm{CI}=95 \%=0.59$ $1.21 \%)$.

Hasil tabulasi silang antara pendidikan ibu dengan pemberian ASI eksklusif didapat bahwa dari 47 orang (59.5\%) ibu yang memiliki pendidikan rendah terdapat 39 orang (49.4\%) ibu yang tidak memberikan ASI eksklusif kepada anaknya. Hal ini dapat disimpulkan bahwa ibu yang memiliki pendidikan rendah dan tidak memberikan ASI eksklusif kepada anaknya memiliki resiko untuk terkena ISPA.

Hal ini sejalan dengan pendapat yang mengatakan bahwa pendidikan akan membuat seseorang terdorong untuk ingin tahu, mencari pengalaman sehingga informasi 
yang diterima akan menjadi pengetahuan. Pendidikan diperkirakan ada kaitannya dengan pengetahuan bahwa seseorang yang berpendidikan lebih tinggi akan mempunyai pengetahuan yang lebih luas untuk memberikan ASI eksklusif dibandingkan dengan tingkat pendidikan rendah (Notoadmojo, 2007). Semakin tinggi tingkat pendidikan ibu, maka semakin luas pengetahuan yang dimiliki ibu.

Kurangnya pengetahuan ibu dalam menghadapi masalah kesehatan terutama masalah gizi seperti kurangnya pengetahuan dan keterampilan para ibu untuk memanfaatkan potensi alam misalnya pekarangan rumah. Kurangnya pengetahuan ibu dalam mensosialisasikan anak untuk membiasakan anak hidup bersih seperti mencuci tangan sebelum makan yang dapat mencegah timbulnya kuman penyakit pada saat mengkonsumsi makanan. Karena perilaku hidup bersih juga sangat berpengaruh pada kesehatan balita (Asydhad, 2006).

\section{Faktor Pekerjaan Ibu Yang Mempengaruhi Pemberian ASI Eksklusif Dengan Kejadian ISPA}

Pengaruh pekerjaan dengan kejadian ISPA pada anak batita diperoleh data bahwa dari 29 ibu (36.7\%) bekerja ada $19 \mathrm{ibu}(24.1 \%)$ yang memiliki anak terkena ISPA. Dan dari 50 orang (63.3\%) ibu tidak bekerja ada 38 orang $(48.1 \%)$ ibu memiliki anak yang terkena ISPA. Hasil uji statistik chi-square didapat nilai $\mathrm{p}=0,458>\alpha=0,05$ artinya tidak ada hubungan pekerjaan terhadap pengaruh pemberian ASI eksklusif dengan kejadian ISPA.

Hasil penelitian ini sejalan dengan penelitian Audinarayana (2005) menunjukkan bahwa tidak adanya hubungan yang bermakna antara pekerjaan ibu dengan kejadian ISPA pada anak $(\mathrm{OR}=1.1 \%$; $\mathrm{p}$ value $>0.10 \%)$ dan hasil penelitian ini juga sejalan dengan penelitian Fauzi, 2008 tentang pengaruh pemberian ASI eksklusif dengan kejadian ISPA pada anak usia 6-23 bulan $(\mathrm{RR}=0.5 \%$; $\mathrm{CI}$ $95 \%=0.23 \%-1.28 \%$ ).

Hasil tabulasi silang antara pekerjaan ibu dengan pemberian ASI eksklusif, dari 50 orang $(63.3 \%)$ ibu yang tidak bekerja terdapat 39 orang $(49.4 \%)$ ibu yang tidak memberikan ASI eksklusif pada anaknya dan hasil tabulasi silang antara pekerjaan dengan anggota keluarga yang merokok didapat hasil dari 50 orang $(63.3 \%)$ ibu yang tidak bekerja terdapat 34 orang (43\%) memiliki anggota keluarga yang merokok. Hal ini dapat disimpulkan bahwa ibu yang tidak bekerja dengan rendahnya pemberian ASI eksklusif dan ada memiliki anggota keluarga yang merokok dapat menimbulkan resiko terkena ISPA pada anak batita.

Jenis pekerjaan ibu maupun suami akan mencerminkan keadaan sosial ekonomi keluarga. Berdasarkan pekerjaan tersebut dapat dilihat kemampuan mereka terutama dalam pemenuhan makanan bergizi sehingga orangtua kurang memperhatikan kondisi kesehatan anaknya. Pekerjaan sangat mempengaruhi status kesehatan keluarga karena semakin tinggi status pekerjaan maka semakin baik pula status kesehatan keluarga tersebut. Semakin tinggi penghasilan maka makin besar pula persentase dari penghasilan tersebut untuk membeli berbagai jenis bahan makanan, sehingga penghasilan juga merupakan faktor penting bagi kuantitas dan kualitas gizi keluarga (Hidayat, 2007).

\section{Faktor Paritas Ibu Yang Mempengaruhi Pemberian ASI Eksklusif Dengan Kejadian ISPA}

Pengaruh paritas dengan kejadian ISPA pada anak batita diperoleh data bahwa dari $32 \mathrm{ibu}(40.5 \%)$ yang memiliki anak < 2 orang ada 19 ibu $(24.1 \%)$ yang memiliki anak terkena ISPA. Dan dari 47 orang $(59.5 \%)$ ibu yang memiliki anak $>2$ orang ada 38 orang (48.1\%) ibu memiliki anak yang terkena ISPA. Hasil uji statistik chi-square didapat nilai $\mathrm{p}=0,067>0,05$ artinya tidak ada hubungan paritas terhadap pengaruh pemberian ASI eksklusif dengan kejadian ISPA.

Tidak adanya hubungan antara paritas dengan kejadian ISPA disebabkan karena ibu yang memiliki paritas > 2 banyak tidak memberikan ASI eksklusif. Disamping itu juga hasil tabulasi silang antara paritas dan anggota yang merokok bahwa dari 47 orang (59.5\%) ibu yang memiliki paritas $>2$ anak terdapat 35 orang (44.3\%) anak yang memiliki anggota keluarga yang merokok. Sementara itu hasil tabulasi silang antara paritas dengan ASI eksklusif didapat hasil bahwa dari 47 orang (59.5\%) ibu yang memiliki paritas > 2 anak terdapat 38 orang (48.1\%) tidak memberikan ASI eksklusif.

\section{Faktor Status Gizi Yang Mempengaruhi Pemberian ASI Eksklusif Dengan Kejadian ISPA \\ Pengaruh status gizi dengan kejadian ISPA pada} anak batita diperoleh data bahwa dari 77 anak (97.5\%) yang memiliki gizi baik ada 55 anak (69.6\%) yang terkena ISPA. Dan dari 2 orang (2.5\%) anak yang memiliki gizi kurang seluruhnya anak yang terkena ISPA.

Hasil uji statistik chi-square didapat nilai $\mathrm{p}=1.000$ $>\alpha=0,05$ artinya tidak ada hubungan status gizi terhadap pengaruh pemberian ASI eksklusif dengan kejadian ISPA. Tetapi secara praktis terdapat bahwa pada anaka dengan status gizi kurang lebih besar resikonya untuk mendapatkanpenyakit ISPA. Hasil penelitian ini sejalan dengan penelitian Fauzi, status gizi tidak bermakna secara statistik terhadap kejadian ISPA.

Hasil penelitian ini sejalan dengan penelitian yang dilakukan oleh Etiler et al (2010) status gizi tidak bermakna secara statistik kejadian ISPA $(\mathrm{RR}=1.11 \% ; \mathrm{CI}=95 \%=0.91-1.37)$ tetapi berbeda dengan penelitian yang dilakukan oleh Nandi (2005) mendapatkan adanya hubungan bermakna antara status gizi dengan kejadian ISPA $(\mathrm{OR}=1.16 \%$; $\mathrm{CI}=95 \%=1.01-1.33)$.

Kekurangan gizi dapat terjadi pada bayi dan anak yang mengakibatkan gangguan pertumbuhan dan perkembangan yang apabila tidak diatasi secara dini dapat berlanjut hingga dewasa. Usia batita merupakan masa pertumbuhan dan perkembangan yang pesat, sehingga kerap diistilahkan sebagai periode emas sekaligus priode kritis. Priode emas dapat diwujudkan apabila masai bayi dan anak memperoleh asupan gizi yang sesuai untuk tumbuh kembang optimal (Prabu, 2009). 


\section{Faktor Status Imunisasi Yang Mempengaruhi Pemberian ASI Eksklusif Dengan Kejadian ISPA}

Pengaruh status imunisasi dengan kejadian ISPA pada anak batita diperoleh data bahwa dari 79 anak (100\%) yang memiliki status imunisasi lengkap ada 57 anak (77.2\%) yang terkena ISPA. Hasil uji statistik chi-square didapat nilai $\mathrm{p}>\alpha=0,05$ artinya tidak ada hubungan status imunisasi terhadap pengaruh pemberian ASI eksklusif dengan kejadian ISPA.

Penelitian ini sejalan dengan penelitian Fauzi (2008) yang menyatakan bahwa tidak ada hubungan yang bermakna antara status imunisasi dengan pengaruh pemberian ASI eksklusif dengan kejadian ISPA ( $p$ value $=0.390 ; \mathrm{RR}=1.6 \%$ ) dan penelitian ini juga sejalan dengan penelitian yang dilakukan ole Ghofur (2005) yang menyatakan bahwa status gizi tidak mempunyai hubungan dengan kejadian ISPA ( $\mathrm{RR}=1.95 \%$; $\mathrm{Cl}=95 \%=0.89-1.88)$.

Bayi dan balita yang pernah terserang campak dan selamat akan mendapat kekebalan alami terhadap pneumonia sebagai komplikasi campak. Sebagian besar kematian ISPA berasal dari jenis ISPA yang berkembang dari penyakit yang dapat dicegah dengan imunisasi seperti difteri, pertusis, campak, maka peningkatan cakupan imunisasi akan berperan besar dalam upaya pemberantasan ISPA. Untuk mengurangi faktor yang meningkatan mortalitas ISPA, diupayakan imunisasi lengkap. Bayi dan balita yang mempunyai status imunisasi lengkap bila menderita ISPA dapat diharapkan perkembangan penyakitnya tidak akan menjadi berat (Maryunani, 2010).

Batita yang status imunisasinya tidak lengkap lebih banyak yang menderita ISPA daripada batita yang status imunisasinya lengkap, ini karena kekebalan tubuh anak batita juga dipengaruhi oleh status imunisasi, oleh karena itu imunisasi sangat penting karena peluang untuk terkena penyakit terutama ISPA lebih kecil dibandingkan anak yang status imunisasinya tidak lengkap. Tetapi hal itu tidak sejalan dengan hasil penelitian yang ada dikarenakan seluruh batita yang ada di Puskesmas Singosari seluruhnya memiliki status imunisasi lengkap, ini disebabkan karena program pemerintah yang baru menyatakan bahwa seluruh anak harus mendapatkan imunisasi, agar hal ini bisa berjalan diadakan sistem menjemput bola oleh kader disetiap diadakan posyandu di beberapa kelurahan yang ada di Puskesmas Singosari.

Hal ini memang tidak sejalan antara status imunisasi dengan kejadian ISPA, tapi kita dapat melihat dari hasil tabulasi silang antara status imunisasi dengan pemberian ASI eksklusif. Di dapat hasil bahwa dari seluruh anak dengan imunisasi lengkap (100\%) ternyata $75 \%$ tidak mendapatkan ASI eksklusif. Kurangnya pemberian ASI eksklusif dapat membuat sistem kekebalan tubuh anak rendah, karena zat kekebalan tubuh sangat banyak terkandung dalam ASI.

\section{Faktor Anggota Yang Merokok Yang Mempengaruhi Pemberian ASI Eksklusif Dengan Kejadian ISPA}

Pengaruh anggota yang merokok dengan kejadian ISPA pada anak batita diperoleh data bahwa dari 53 anak (67.1\%) yang memiliki anggota keluarga yang merokok ada 44 anak (55.7\%) yang terkena ISPA. Dan dari 26 orang $(32.9 \%)$ anak yang tidak memiliki anggota keluarga yang merokok ada 13 orang (16.5\%) anak yang terkena ISPA. Hasil uji statistik chi-square didapat nilai $\mathrm{p}=0,005$ artinya ada hubungan anggota yang merokok terhadap pengaruh pemberian ASI eksklusif dengan kejadian ISPA.

Hasil penelitian ini sejalan dengan penelitian Bachrach et al (2003) menemukan bahwa orangtua yang merokok mempunyai hubungan yang bermakna dengan kejadian ISPA (RR $=0.043 ; \mathrm{CI} 95 \%=0.22 \%-0.85 \%)$. Dan ini juga sejalan dengan penelitian Maryani (2012) menemukan bahwa hubungan kondisi lingkungan rumah dan keluarga yang merokok dengan kejadian ISPA pada anak balita mempunya hubungan yang yang bermakna ( $p$ value $=0.001<0.05$ ). Pada anak yang hanya diberi ASI 0-6 bulan dan memiliki anggota keluarga yang merokok meningkatkan resiko terjadinya ISPA.

Pada variabel anggota keluarga yang merokok, didapatkan bahwa sebagian besar subjek (55.7\%) terpapar dengan asap rokok baik dari oran gtua maupun dari anggota keluarga lainnya. Asap rokok yang terhisap oleh anak akan mempengaruhi aktivitas siliar saluran nafas (siliar rongga hidung) dan menghambat mekanisme pertahanan lokal lain. Sehingga apabila ada kuman yang masuk melalui saluran nafas, sistem pertahanan tubuh anak tidak bekerja maksimal.

\section{KESIMPULAN DAN SARAN}

\section{Kesimpulan}

Ada pengaruh pemberian ASI eksklusif dengan kejadian ISPA, hasil uji statistik chi-square didapat nilai $p$ $=0,002$. Karakteristik anak dengan kejadian ISPA yang berhubungan yaitu anggota keluarga yang merokok, dengan nilai $p=0.005$.

\section{Saran}

Diharapkan ibu-ibu yang memiliki batita untuk dapat memperhatikan atau menambah gizi pada anaknya dan memperhatikan kelengkapan imunisasinya dan kepada petugas kesehatan diharapkan dapat meningkatkan cakupan ASI eksklusif diperlukan monitoring langsung dari bidan terhadap ibu nifas untuk memberikan ASI eksklusif.

\section{DAFTAR PUSTAKA}

Abdullah, 2003. Hubungan Pemberian ASI Eksklusif Dengan Kejadian Pneumonia Pada Anak Balita, Universitas Negeri Semarang. Semarang.

Asyadhad, 2006, Perilaku Hidup Bersih dan Sehat, Salemba Medika, Jakarta. 
Audinarayana, 2005. Faktor-Faktor yang Mempengaruhi Kejadian ISPA, Universitas Negeri Semarang. Semarang.

Bachrach, 2003. Hubungan Pemberian ASI Eksklusif Dengan Kejadian ISPA. India

Fauzi, 2008. Pengaruh Pemberian ASI Eksklusif Terhadap Kejadian ISPA Pada Usia 6-23 Bulan, Universitas Gadja Mada, Yogyakarta.

Finberg dan Kleinman, 2006. Pengaruh Pemberian ASI Eksklusif Terhadap Kejadian ISPA Pada Usia 623 Bulan, Universitas Gadja Mada, Yogyakarta.

Kementrian Kesehatan RI, 2012. Profil Kesehatan 2011 , Jakarta.

Maryunani, A., 2010. Ilmu Kesehatan Anak Dalam Kebidanan, CV.Trans Info Media, Jakarta Timur.

Maryani, (2012). Hubungan Kondisi Lingkungan Rumah dan Keluarga Yang Merokok Dengan Kejadian ISPA Pada Anak Balita. Universitas Airlangga. Surabaya.

Notoadmojo, S. 2007. Metodologi Penelitian Kesehatan, Rineka Cipta, Jakarta.

,2010, Metode Penelitian Kesehatan, Rineka Cipta, Jakarta

Pediatri, S., 2009. Infeksi Saluran Akut pada Balita Di Daerah Urban Jakarta, http://saripediatri.idai.or.id/pdfile/11-4-1.pdf (Diakses Tanggal 14 Maret 2014, 18:45).

Prabu, 2009. Mengatasi Gangguan Kesehatan Pada Anak anak, PT. Gramedia, Jakarta.

Profil Kesehatan Sumatra Utara, 2012 http://www.depkes.go.id/downloads/PROFIL_K ES_PROVINSI_2012/02_Profil_Kes_Prov.Suma teraUtara_2012.pdf (Diakses tanggal 14 Maret 2014).

Proverawati, A., dan Eni Rahmawati, 2010. Kapita Selekta ASI Menyusui, Nuha Medika, Bantul.

Sentra Laktasi Indonesia, 2007. Universitas Sumatera Utara . Available at : http :// repository .usu.ac.id/bitstream/123456789/34055/4/Chapter \%20I.pdf (Diakses pada tanggal 15 Maret 2014, 19:05).

Sulistyawati A., 2009. Buku Ajar Asuhan Kebidanan Pada Ibu Nifas, Yogyakarta.

USAID, 2010. Manfaat ASI Eksklusif Pada Anak. Jakarta.

Utomo, 2009. Pengaruh pemberian ASI Eksklusif dengan kejadian ISPA pada anak usia 6-23 bulan di kabupaten Konowe. Universitas Gadja Mada:Yogykartahttp://etd.ugm.ac.id/index.php? $\underline{\bmod =\quad \text { penelitian_detail } \& s u b=\quad \text { Penelitian }}$ Detail\&act=view\&typ=html\&buku_id=43243\&o byek_id=4 (Diakses Tanggal 13 Maret 2014, 20:05).

WHO, 2003. Penanganan ISPA Pada Anak Di Rumah Sakit Kecil Negara Berkembang, Kedokteran EGC, Jakarta.
Widya, 2013. Hubungan Pemberian ASI Eksklusif Dengan Kejadian ISPA Pada Anak Balita Di Puskesmas Banjarmasin, Stikes Banjarmasin, Banjarmasin.

Widoyono, 2008. Penyakit Tropis Epidemiologi, Penularan, dan Pemberantasan, Erlangga, Semarang. 